Brazilian Journal of Animal Science

ISSN 1806-9290

www.rbz.org.br

\title{
Broiler carcass condemnation pattern during processing
}

\author{
Rafael Belintani $^{1}$ iD, Rodrigo Garófallo Garcia ${ }^{1}$ iD , Irenilza de Alencar Nääs ${ }^{1}$ iD , \\ Rodrigo Borille $^{1}$ (iD), Sarah Sgavioli ${ }^{2}$ (iD), Fabiana Ribeiro Caldara ${ }^{1}$ (iD), \\ Nilsa Duarte da Silva Lima ${ }^{3^{*}}$ iD \\ ${ }^{1}$ Universidade Federal da Grande Dourados, Faculdade de Ciências Agrárias, Dourados, MS, Brasil. \\ ${ }^{2}$ Universidade Brasil, Descalvado, SP, Brasil. \\ ${ }^{3}$ Universidade Estadual de Campinas, Faculdade de Engenharia Agrícola, Campinas, SP, Brasil.
}

\author{
*Corresponding author: \\ nilsa.silva.lima@gmail.com \\ Received: March 16, 2018 \\ Accepted: February 11, 2019 \\ How to cite: Belintani, R.; Garcia, R. G.; Nääs, I. \\ A.; Borille, R.; Sgavioli, S.; Caldara, F. R. and Lima, \\ N. D. S. 2019. Broiler carcass condemnation \\ pattern during processing. Revista Brasileira de \\ Zootecnia 48:e20180046. \\ https://doi.org/10.1590/rbz4820180046 \\ Copyright: This is an open access article \\ distributed under the terms of the \\ Creative Commons Attribution License \\ (http://creativecommons.org/licenses/by/4.0/), \\ which permits unrestricted use, distribution, \\ and reproduction in any medium, provided the \\ original work is properly cited.
}

\begin{abstract}
This study aimed to identify the influence of climate pattern and rearing conditions on broiler carcass condemnations observed during processing. We evaluated the registered data of 2015 from the federal inspection files in all broiler slaughterhouses located in the state of Mato Grosso do Sul, Midwestern Brazil. The percentages of condemnations by airsacculitis, cellulitis, dermatosis, ascites syndrome, total carcass condemnations, and average broiler weight at 42 days were analyzed. Data were associated with housing systems and season of the year in which each flock was reared. Two-way ANOVA was applied to the data in a completely randomized design $4 \times 3$ (four seasons and three houses) and compared by Tukey's test. The results indicated that the housing system did not affect the studied condemnations, and seasons of the year did not change condemnation by airsacculitis; however, the other pathologies leading to carcass condemnations were affected by season. Condemnations by cellulite were higher during summer than in winter. For dermatosis, the maximum index appears during summer and the lowest during winter and spring. The ascites syndrome presented the smallest index in summer and winter, and the minimum value was found in spring. The average bird weight was higher in autumn than in winter and spring. Type of broiler rearing did not affect the carcass condemnation index. Summer was the most detrimental period regarding the condemnation rates for the pathologies studied, mainly cellulitis and dermatosis, while the highest average weight of birds was found during autumn and spring.
\end{abstract}

Keywords: broiler, meat, production system, slaughterhouse

\section{Introduction}

The economic pressure to reduce broiler production costs, allied to the high cost of feeding and operational price instability, has moved growers to increase flock density worldwide (Cechin et al., 2013; Ebling and Basurco, 2016). However, large flock density increases the heat load inside the rearing environment (Lara and Rostagno, 2013), and heat stress is one of the most critical stressors challenging poultry production. Broiler houses with negative pressure tunnel ventilation are widely used to maintain thermal environmental comfort in tropical countries. High ventilation rate improves productivity indexes even when the flock is reared under high stocking densities (Albright, 1990; Deaton et al., 1997; Gates et al., 2001). The rearing ambient due to cooling and ventilation systems plays a fundamental role in the control of several environmental factors, improving the inlet of fresh air and the removal of excess moisture, dust, odors, and gases (Albright, 1990; Miragliotta et al., 2006). Proper 
ventilation provides oxygen to birds and removes the excess of heat produced by birds, equipment, and heat gain by solar radiation and lighting (Gates et al., 2001; Bucklin et al., 2009).

The need to intensify broiler production to meet market demand contributes to an upsurge of diseases that may result in partial or total carcass condemnations during post-mortem inspection in the commercial slaughterhouses (Sesterhenn et al., 2011; Paschoal et al., 2012; Ebling and Basurco, 2016). This issue implies directly on product quality since it is necessary that the phases of production and processing comply with the norms and regulations applied to the process (Corrêa, 2013). Quality of broiler meat is the aim of all poultry industry. The objective of this study was to verify whether the different rearing systems (conventional, tunnel system, and dark-house) and seasons of the year affect the percentage of broiler carcass condemnation.

\section{Material and Methods}

The protocol DRD approved the research MBPF 10007/03-20 referred to the Animal Welfare Program and validated by the Brazilian Ministry of Agriculture, registered at the Federal Inspection Service no. 18, 076/18/14, of December 10, 2014.

The data recording was carried out in a commercial slaughterhouse located in the state of Mato Grosso do Sul (MS), Brazil. The unit is registered at the Brazilian Ministry of Agriculture (MAPA) with permanent inspection complying with local regulations (Brasil, 1998). The norms define the criteria and destination of the condemned carcasses detected with airsacculitis, cellulitis, dermatosis, and ascites syndrome, which were the purpose of the present study. From January 2nd to December 31st, 2015, the total and partial condemnations officially registered by SIF (Official Inspection of Animal Products) were recorded. The regional climate data and the environmental performance of the rearing systems were recorded.

The climate pattern of the studied region was drawn from data of the meteorological station of the Embrapa Agropecuária Oeste (Embrapa, 2015) located in Dourados $\left(22^{\circ} 16^{\prime} 30^{\prime \prime} \mathrm{S}, 54^{\circ} 49^{\prime} 00^{\prime \prime} \mathrm{W}\right.$, and $408 \mathrm{~m}$ altitude). The climatic factors considered in the current study were regional environmental temperature (maximum and minimum), relative humidity (maximum and minimum), wind velocity, and rain index (Table 1). Broiler production system is usually characterized by some variables as the capacity of rearing in a floor area (flock density, $\mathrm{m}^{2}$ ) which is related to the microclimate in the region where the housing is located.

The commercial company in the present study has a vertical broiler production system integrated with the processing industry. The broiler houses were located at an average distance of $80 \mathrm{~km}$ from the slaughterhouse, and the houses were defined based on the adopted ventilation system. There were three kinds of houses: conventional (CV), tunnel system (TS), and dark-house system (DH). The CV had open-side structure with polypropylene curtains closing the side walls, and axial fans positioned towards the air outlet, with a maximum flow capacity of $60 \mathrm{~m}^{3} \mathrm{~s}^{-1}$, and high-pressure fogging system

Table 1 - Characterization of the mesoregion climate

\begin{tabular}{|c|c|c|c|c|c|c|c|c|}
\hline \multirow{3}{*}{ Season } & \multicolumn{8}{|c|}{ Climate variable $^{1}$} \\
\hline & \multicolumn{3}{|c|}{ Temperature $\left({ }^{\circ} \mathrm{C}\right)$} & \multicolumn{3}{|c|}{ Relative humidity (\%) } & \multirow{2}{*}{$\begin{array}{l}\text { Wind speed } \\
\qquad\left(\mathrm{m} \mathrm{s}^{-1}\right)\end{array}$} & \multirow{2}{*}{$\begin{array}{l}\text { Rain index } \\
\quad(\mathrm{mm})\end{array}$} \\
\hline & Mean & Max & Min & Mean & Max & Min & & \\
\hline Autumn & 21.30 & 27.41 & 16.53 & 79.33 & 93.90 & 54.64 & 0.83 & 4.84 \\
\hline Winter & 21.28 & 28.30 & 14.84 & 65.53 & 86.26 & 41.44 & 1.20 & 3.05 \\
\hline Spring & 24.43 & 30.31 & 19.58 & 76.98 & 92.21 & 54.43 & 1.24 & 9.95 \\
\hline Summer & 25.57 & 32.31 & 21.25 & 77.71 & 92.79 & 50.42 & 1.22 & 4.91 \\
\hline Mean & 23.14 & 29.58 & 18.05 & 74.89 & 91.29 & 50.23 & 1.12 & 5.69 \\
\hline
\end{tabular}

Max - maximum; Min - minimum.

${ }^{1}$ Means of climatic data from 2015 for the mesoregion of Dourados, Mato Grosso do Sul, Brazil. Source: Embrapa Agropecuária Oeste (Embrapa, 2015). 
distributed in two lines along the house. The TS had open side structure with polypropylene curtains closing the side walls, and axial fans positioned all towards the air outlet, with a maximum flow capacity of $100 \mathrm{~m}^{3} \mathrm{~s}^{-1}$ and high-pressure fogging system distributed in two lines along the house. The DH had forced ventilation with exhaust fans with a maximum airflow of $300 \mathrm{~m}^{3} \mathrm{~s}^{-1}$, a high-pressure fogging system distributed in two lines along the house, and the side walls were built with brick using a black coating in the internal area.

The male birds were from the genetic Cobb ${ }^{\circledR}$ strain and were reared using a mean flock density compatible with the rearing system, 12 birds $\mathrm{m}^{-2}\left(27.6 \mathrm{~kg} \mathrm{~m}^{-2}\right)$ in $\mathrm{CV}, 13$ birds m $\mathrm{m}^{-2}\left(32.5 \mathrm{~kg} \mathrm{~m}^{-2}\right)$ in TS, and 14 birds m $\mathrm{m}^{-2}\left(36.4 \mathrm{~kg} \mathrm{~m}^{-2}\right)$ in DH. Broilers were slaughtered at 42 days old, and the data were evaluated regarding the type of condemnation, day of slaughter (for the determination of the season of the year), flock type of rearing system, and mean weight of the birds ( $\mathrm{kg} \mathrm{bird}^{-1}$ at slaughter). The absolute number of condemnations of each flock and the condemnation data were transformed into a percentage value of the total of broiler slaughtered for proceeding with the statistical analysis.

Data from 2,165 flocks available by the Federal Inspection Service (SIF, Brazil) of 2015 were collected. The total of data were distributed in the four seasons of the year: summer ( $=555$ flocks), autumn ( $\mathrm{n}=519$ flocks), winter $(\mathrm{n}=551$ flocks), and spring $(\mathrm{n}=540$ flocks). Considering the rearing systems, the data collected were CV ( $\mathrm{n}=1931$ flocks) with 12 birds $\mathrm{m}^{-2}$, TS ( $\mathrm{n}=50$ flocks) with 13 birds m$^{-2}$, and DH ( $\mathrm{n}=184$ flocks) with 14 birds $\mathrm{m}^{-2}$. Data normality were checked. The percentage of each studied condemnation (airsacculitis, cellulitis, dermatosis, and ascites syndrome) and the mean weight of birds at slaughter $(\mathrm{kg})$ were subjected to Pearson correlation for determining the possible relations between the variables. In the analysis, the variable grower was introduced to indicate the origin of the flock and determine whether the farm influenced the found condemnations and mean weight of broilers.

Two-way ANOVA was applied to registered data using a completely randomized factorial $4 \times 3$ arrangement (four seasons of the year and three types of rearing system). When the ANOVA showed a significant difference $(\mathrm{P}<0.05)$, the means were compared using Tukey's test adopting the probability of $95 \%$. All statistical procedures were done using the software SAS software (Statistical Analysis System, version 9.4). Pearson correlation is a parametric measure of association between two continuous random variables. Correlation procedure used in this analysis presents a table of Pearson product-moment correlations, which range from -1 to +1 . To find the correlation coefficients between a pair of variables in the dataset, we used the PROC CORR of SAS.

\section{Results}

The climatic patterns of the mesoregion of Dourados (Table 1) presented average maximum temperatures of $32.31{ }^{\circ} \mathrm{C}$ during summer and $30.31{ }^{\circ} \mathrm{C}$ in spring, with average maximum relative humidity of 92.79 and 92.21 , respectively. In spring, precipitation was higher than in the other season, with a mean of $9.95 \mathrm{~mm}$ (IBGE, 1990; Embrapa, 2015).

Pearson correlation between farm and airsacculitis $(-0.10)$, ascites syndrome $(-0.11)$, mean weight $(-0.25)$, cellulitis $(-0.30)$, dermatosis $(-0.36)$, and total condemnation $(-0.36)$ had a negative correlation (Table 2). These results indicate a weak negative relationship between the variables. Farm presented a very weak positive association with rearing system $(0.04)$ and number of broilers (0.04). Rearing system presented a positive correlation with number of broilers $(0.84)$, which indicates a strong relationship between the two. There was a weak positive correlation between airsacculitis and dermatosis (0.14), ascites syndrome (0.17) and cellulitis (0.29), and a moderate positive association between airsacculitis and total condemnation (0.40). Cellulitis and total condemnation (0.93) presented a very strong positive correlation, indicating that the higher the percentage of condemnation by cellulitis, the higher the percentage of total condemnation (Figure 1). The correlation between cellulitis and dermatosis (0.56), and between dermatosis and total condemnation (0.80) were moderately positive. These results indicate that diseases related to the rearing air quality and the similar results found for cellulitis and dermatosis are probably justified by the use of large flock density and a possibility of heat stress exposure.

R. Bras. Zootec., 48:e20180046, 2019 
The rearing systems $(\mathrm{P}=0.09)$ and different seasons of the year $(\mathrm{P}=0.15)$ did not affect the percentage of condemnation by airsacculitis (Table 3). The season of the year on the incidence of cellulitis (1.31; $\mathrm{P}=0.0001)$ and dermatosis $(1.05 ; \mathrm{P}=0.0001)$ in the summer presented non-significant results. The rearing system did not differ for condemnation by airsacculitis and ascites syndrome. No interaction was found between type of rearing system and season of the year for cellulitis $(P=0.40)$ and dermatosis $(P=0.19)$. No effect was found of type of rearing system on the incidence of condemnation by dermatosis. However, the impact of season of the year is noted, as during summer the number of condemnations increased. The mean values of carcass condemnations during autumn appeared in the second place in the appearance of the disease, followed by spring and winter. Condemnations by dermatosis were

Table 2 - Analysis of Pearson correlation between the variables studied

\begin{tabular}{|c|c|c|c|c|c|c|c|c|}
\hline & Farm & $\begin{array}{l}\text { Rearing } \\
\text { system }\end{array}$ & Airsacculitis & Cellulitis & Dermatosis & $\begin{array}{c}\text { Ascites } \\
\text { syndrome }\end{array}$ & $\begin{array}{c}\text { Total } \\
\text { condemnation }\end{array}$ & $\begin{array}{c}\text { Number of } \\
\text { broilers }\end{array}$ \\
\hline Rearing system & 0.04 & & & & & & & \\
\hline P-value & 0.04 & & & & & & & \\
\hline Airsacculitis & -0.10 & -0.05 & & & & & & \\
\hline P-value & 0.00 & 0.02 & & & & & & \\
\hline Cellulitis & -0.30 & -0.06 & 0.29 & & & & & \\
\hline P-value & 0.00 & 0.01 & 0.00 & & & & & \\
\hline Dermatosis & -0.36 & -0.04 & 0.14 & 0.56 & & & & \\
\hline P-value & 0.00 & 0.08 & 0.00 & 0.00 & & & & \\
\hline Ascites syndrome & -0.11 & 0.02 & 0.17 & 0.23 & 0.29 & & & \\
\hline P-value & 0.00 & 0.45 & 0.00 & 0.00 & 0.00 & & & \\
\hline Total condemnation & -0.36 & -0.06 & 0.40 & 0.93 & 0.80 & 0.35 & & \\
\hline P-value & 0.00 & 0.01 & 0.00 & 0.00 & 0.00 & 0.00 & & \\
\hline Number of broilers & 0.04 & 0.84 & -0.03 & -0.09 & -0.08 & -0.04 & -0.09 & \\
\hline P-value & 0.05 & 0.00 & 0.13 & 0.00 & 0.00 & 0.07 & 0.00 & \\
\hline Mean weight & -0.25 & -0.05 & 0.01 & 0.09 & 0.08 & 0.01 & 0.09 & -0.08 \\
\hline P-value & 0.00 & 0.04 & 0.73 & 0.00 & 0.00 & 0.76 & 0.00 & 0.00 \\
\hline
\end{tabular}

Correlation is significant when $\mathrm{P}<0.05$.

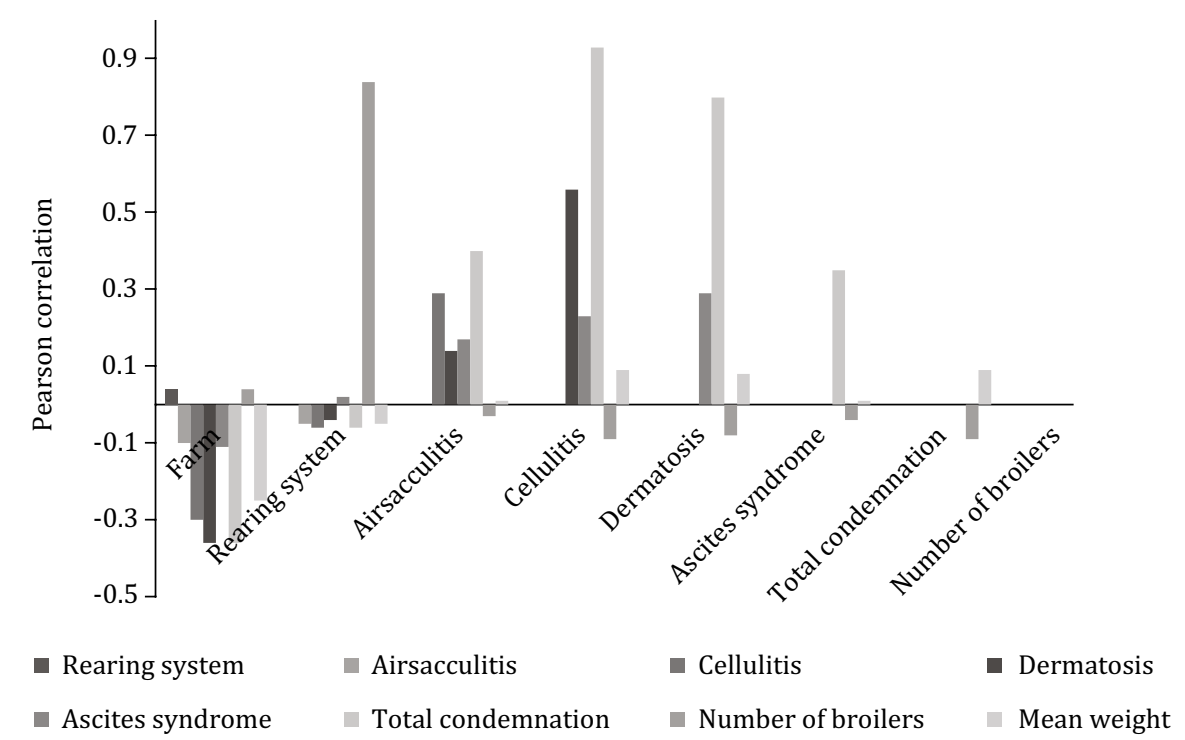

Figure 1 - Pearson correlation between the variables rearing system, airsacculitis, cellulitis, dermatosis, ascites syndrome, total condemnation, number of broilers, and mean weight of broilers. 
higher during the hottest months of the year than during the other periods. Those results may be due to the body contact with litter to increase heat loss. Condemnations by ascites syndrome were not affected by rearing system. No interaction was found between housing systems and seasons of the year.

The sum of all the condemnations by airsacculitis, cellulite, dermatosis, and ascites syndrome, from each flock, represented here by the total percentage of condemnations variable (Table 4), is an attempt to clarify the factors that result in significant condemnation results in the slaughterhouse. The results of the index confirm that type of rearing system did not affect the total number of condemnations. No interaction was found between rearing system and season of the year. The mean weight of broilers did not differ at 42 days old (slaughter age) (Table 5). However, the weight changed in the various seasons of the year. Weight of broilers slaughtered in the months of autumn was higher than in those of the other seasons. Despite the significant value of carcass condemnations in summer, during this season, broilers had the second best mean weight at slaughter; the lowest mean weight was found during spring and winter.

\section{Discussion}

Type of rearing system and seasons of the year did not affect the condemnations by airsacculitis (Table 3). These results differ from those found by Olivo (2006) that indicate that the incidence of septicemia, tumors, and airsacculitis is higher in autumn and winter than in the other seasons, while the occurrence of cellulitis is higher in spring and summer. In a study in two slaughterhouses in Midwestern Brazil, Santana et al. (2008) found a small percentage of condemnations by cellulitis and attributed it to broiler management. Condemnations by airsacculitis in the current study were relatively low when

Table 3 - Percentage of condemnation by airsacculitis (AC), cellulitis (CL), dermatosis (DM), and ascites syndrome (AS) in broilers from different rearing systems and season of the year

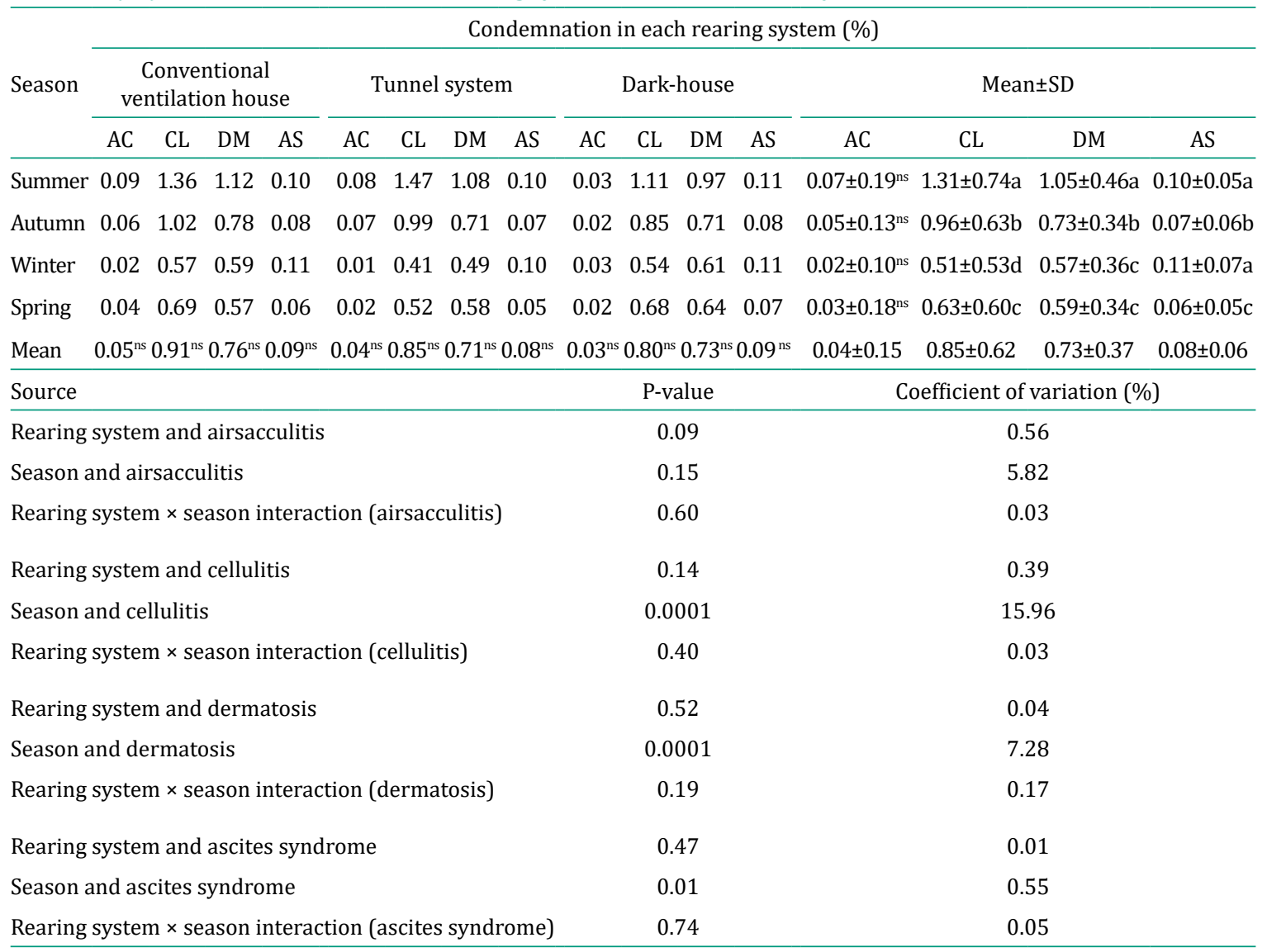

SD - standard deviation.

ns - not significant by ANOVA $(\mathrm{P}<0.05)$. 
compared with those found by Moura et al. (2012). The inflammation of one or more of the air sacs was also the most significant cause of partial turkey carcass condemnation described by Macahyba et al. (2005) in a study in Southern Brazil. However, Schlestein (2007) found that this disease was the sixth cause of carcass condemnation (5.71\%) in another research.

The climate of the mesoregion of Dourados, MS, Brazil is hot and humid during summer and mild and dry in winter. The mean regional annual temperature was $23.14^{\circ} \mathrm{C}$. In summer, the mean temperature was $25.57^{\circ} \mathrm{C}$. The mean temperature in autumn was $21.30^{\circ} \mathrm{C}$ and $21.28^{\circ} \mathrm{C}$ in winter, while in spring, it was $24.43^{\circ} \mathrm{C}$ (Table 1). The seasonal variation in the environmental temperature may have influenced the carcass condemnation results on airsacculitis when comparing the present results with those found in the Southern region of Brazil (Macahyba et al., 2005).

The Dourados metropolitan area corresponds to 10 microregions (IBGE, 1990) with significant broiler production primarily for the export market. Considering the broiler production data of 2015, broiler slaughter in Mato Grosso State, where Dourados region is located, corresponds to 3.22\% $(423,3012)$ and $4.02 \%(173,021)$ of the total Brazilian export, which was 13,146 ton (ABPA, 2016). Computing the losses by carcass condemnation in relation to rearing system (Table 4), the results show that 26.18 are lost by flock $\left(0.022\right.$ broilers $\left.\mathrm{m}^{-2}\right)$ in the CV system; 49.32 broilers per flock $\left(0.022\right.$ birds $\left.\mathrm{m}^{-2}\right)$ in TS; and 55.37 boilers per flock $\left(0.023\right.$ birds $\left.\mathrm{m}^{-2}\right)$ in $\mathrm{DH}$. The losses were similar in all rearing systems and

Table 4 - Percentage of total condemnation of broilers from different rearing systems and seasons of the year

\begin{tabular}{|c|c|c|c|c|}
\hline \multirow{2}{*}{ Season } & \multicolumn{3}{|c|}{ Type of rearing system } & \multirow{2}{*}{ Mean \pm SD } \\
\hline & $\mathrm{CV}$ & TS & DH & \\
\hline Summer & 2.68 & 2.73 & 2.22 & $2.54 \pm 1.07 \mathrm{a}$ \\
\hline Autumn & 1.93 & 1.84 & 1.67 & $1.82 \pm 0.95 b$ \\
\hline Winter & 1.30 & 1.01 & 1.29 & $1.20 \pm 0.80 c$ \\
\hline Spring & 1.37 & 1.17 & 1.41 & $1.31 \pm 0.89 c$ \\
\hline Mean & $1.82^{\text {ns }}$ & $1.69^{\mathrm{ns}}$ & $1.65^{\mathrm{ns}}$ & $1.72 \pm 0.93$ \\
\hline Source & & P-value & \multicolumn{2}{|c|}{ Coefficient of variation (\%) } \\
\hline Rearing system & & 0.20 & \multicolumn{2}{|c|}{0.40} \\
\hline Season & & 0.00 & \multicolumn{2}{|c|}{36.63} \\
\hline Rearing system & on & 0.19 & \multicolumn{2}{|c|}{8.17} \\
\hline
\end{tabular}

CV - conventional ventilation house; TS - tunnel system; DH - dark-house; SD - standard deviation.

ns - not significant by ANOVA $(\mathrm{P}<0.05)$.

Different letters in the column represent the statistical difference between means by the Tukey test $(\mathrm{P}<0.05)$.

Table 5 - Mean body weight at slaughter from different rearing systems and seasons of the year

\begin{tabular}{lcccc}
\hline \multirow{2}{*}{ Season } & \multicolumn{4}{c}{ Mean weight of broilers at slaughter (42 days old; kg) } \\
\cline { 2 - 5 } & $\mathrm{CV}$ & $\mathrm{TS}$ & $\mathrm{DH}$ & Mean \pm SD \\
\hline Summer & 2.77 & 2.81 & 2.71 & $2.76 \pm 0.19 \mathrm{~b}$ \\
Autumn & 2.85 & 2.82 & 2.78 & $2.82 \pm 0.20 \mathrm{a}$ \\
Winter & 2.68 & 2.75 & 2.65 & $2.70 \pm 0.18 \mathrm{c}$ \\
Spring & 2.66 & 2.64 & 2.71 & $2.67 \pm 0.20 \mathrm{c}$ \\
Mean & $2.74^{\mathrm{ns}}$ & $2.76^{\mathrm{ns}}$ & $2.71^{\mathrm{ns}}$ & $2.74 \pm 0.19$ \\
\hline Source & & \multicolumn{2}{c}{ Coefficient of variation (\%) } \\
\hline Rearing system & & \multicolumn{2}{c}{0.001} \\
Season & 0.40 & \multicolumn{2}{c}{0.13} \\
Rearing system $\times$ season interaction & 0.01 & \multicolumn{2}{c}{0.02} \\
\hline
\end{tabular}

CV - conventional ventilation house; TS - tunnel system; DH - dark-house, SD - standard deviation.

ns - not significant by ANOVA $(\mathrm{P}<0.05)$.

Different letters in the column represent the statistical difference between means by the Tukey test $(\mathrm{P}<0.05)$. 
might be associated with other factors such as genetic strain, metabolism, or health (Amini et al., 2015; Salines et al., 2017).

In the current study, no interaction between type of rearing system and season was found related to carcass condemnation by airsacculitis. However, the highest incidence of airsacculitis was during summer, and the smallest rate during winter (Table 4). Carcass condemnation by airsacculitis is highly expressive in Brazil (Brasil, 2013). In 2012, five billion broilers were slaughtered, and nine million were condemned because of cellulitis, representing the fourth highest cause of condemnation in that year (7\%). The other expressive condemnations were biological contamination (30\%), bruising (13\%), and dermatosis (13\%). The present study showed results lower than the mean national rate, probably due to proper management during the pre-slaughter logistics adopted by the studied company. Santos (2007) observed the behavior of broilers reared in DH and found that birds tend to increase body surface to improve heat loss during the hot weather by opening the wings and laying down on litter, which increased cellulitis in the flock. Garcia et al. (2002) suggested that DH decrease broiler feathering, which implies in a higher incidence of carcass lesions than in other rearing systems. Rearing system also did not affect the incidence of condemnations by dermatosis (Table 3). An isolated effect was found of season, and during summer, the condemnations by dermatosis increased. Carcass condemnations by dermatitis are mainly found in the abdominal area of the bird. The litter is a microbiological source of several pathogens such as Salmonella sp., Campylobacter, and Escherichia coli (E. coli), particularly the bacterial strains that cause necrotic dermatitis in broilers. Condemnation by dermatosis was higher in the present study during summer (which is a humid and hot season) than in the other seasons (Fiorentin, 2005).

The reduction of stocking density during the rearing period of growth might contribute to decreasing the locomotor issues in broilers (Sorensen et al., 2000; Knowles et al., 2008), contact dermatitis (Bessei, 2006), and scratches and bruises (Sorensen et al., 2000; Arnould and Faure, 2003; Dozier et al., 2005). However, in the current study, no difference was found in the number of condemnations by dermatitis in broilers from the studied types of rearing systems with different flock densities ( 12 birds $\mathrm{m}^{-2}$ in $\mathrm{CV}$, 13 birds $\mathrm{m}^{-2}$ in TS, and 14 birds $\mathrm{m}^{-2}$ in DH). The type of rearing system did not affect the incidence of carcass condemnations by the ascites syndrome (Table 2). Neither an interaction was observed in the incidence of carcass condemnations between the rearing systems and season of the year. However, there was an isolated effect of season in the number of condemnations by ascites syndrome. The explanation for this result may be the low concentration of oxygen in the ambient, as mentioned in the literature (Miragliotta et al., 2006; Paschoal et al., 2012). As the broilers have low lung expansion, the organs do not tolerate high heart demand (Macari and Givisiez, 2002), justifying the results obtained by ascites syndrome in summer when heat stress is often found in all rearing systems. Cordeiro et al. (2011) attributed the incidence of ascites syndrome in late age to the deficiency of heat during the brooding phase in the first weeks of growth. That information may be consistent with the results found of number of condemnations by ascites syndrome during winter, but it does not justify the results for summer.

Another hypothesis for the incidence of ascites syndrome is the high presence of body fat that produces a lower caloric increment than the feed protein and carbohydrate metabolism (Lara and Rostagno, 2013). The incidence of ascites syndrome is also related to the high environmental temperatures, which reduce the ingestion of nutrients and affect the bird metabolism (Lin et al., 2006). When exposed to heat stress, birds increase panting, which may change the metabolism (Nascimento et al., 2009; Amaral et al., 2011).

The rearing system did not affect the number of condemnations, and no interaction between rearing system and season of the year was observed. However, during summer, the most substantial amount of condemnations was found nearly $1 \%$ higher than that during autumn, which is known as the period of an intermediate number of carcass condemnations. Mean condemnations in winter and spring were low. The high amount of carcass condemnation during summer is probably due to the lack of proper ventilation in the rearing systems and the difficulty of broilers in coping with the heat stress (Calefi et al., 2017). 
The type of rearing system did not affect the mean weight of birds at slaughter (Table 3). Seasons presented different values of condemnations. The mean weight of broilers was higher in autumn than in the other seasons. Mortari et al. (2002) evaluated the performance of broiler chickens reared at different densities during winter period in Southern Brazil and observed that good feed conversion and final weight were more associated to the efficiency of the rearing environment than to stocking density or season. In the present study, the mean weight of the flocks in summer and spring were higher than those in autumn and winter, probably due to failures in controlling the internal environment of sheds in the three rearing systems (CV, TS, and DH).

Souza et al. (2010) evaluated flocks of broilers in Southern Brazil and found an effect of seasons on the performance of 43-day-old broilers, being the lowest during spring. During winter, birds need to consume energy to maintain its thermoneutral temperature, justifying the high feed conversion. The data presented (Table 5) show an average flock weight during winter inferior to those in the summer and autumn, which reaffirms the use of energy by the birds to maintain body temperature constant.

\section{Conclusions}

The type of rearing system does not influence carcass condemnations, although the systems were different, and the dark-house system used a higher housing density and more accurate environment control. Summer was the most detrimental period regarding the condemnation rates for the pathologies studied, mainly cellulitis and dermatosis, while the highest average weight of birds was found during autumn and spring.

\section{References}

ABPA - Associação Brasileira de Proteína Animal. Available at: <http://abpa-br.com.br/setores/avicultura/publicacoes/ relatorios-anuais>. Accessed on: Jul. 19, 2016.

Albright, L. D. 1990. Environment control for animals and plants. American Society of Agricultural and Biological Engineers Press, St. Joseph.

Amaral, A. G.; Yanagi Junior, T.; Lima, R. R.; Teixeira, V. H. and Schiassi, L. 2011. Efeito do ambiente de produção sobre frangos de corte sexados criados em galpão comercial. Arquivo Brasileiro de Medicina Veterinária e Zootecnia 63:649-658. https://doi.org/10.1590/S0102-09352011000300017

Amini, K.; Zachar, T.; Popowich, S.; Knezacek, T.; Goodhope, B.; Willson, P. and Gomis, S. 2015. Association of increased rate of condemnation of broiler carcasses due to hepatic abnormalities with immunosuppressive diseases in the broiler chicken industry in Saskatchewan. Canadian Journal of Veterinary Research 79:261-267.

Arnould, U. and Faure, J. M. 2003. Use of pen space and activity of broiler chickens reared at two different densities. Applied Animal Behavior Science 84:281-296.

Bessei, W. 2006. Welfare in broilers: a review. World's Poultry Science Journal 62:455-566. https://doi.org/10.1017/ S0043933906001085

Brasil. Ministério da Agricultura, Pecuária e Abastecimento. 1998. Portaria $\mathrm{n}^{\circ}$ 210, de 10 de novembro de 1998. Aprova o regulamento técnico da inspeção tecnológica e higiênico-sanitária de carne de aves. Diário Oficial da República Federativa do Brasil, Brasília, DF.

Brasil. Ministério da Agricultura, Pecuária e Abastecimento. 2013. Available at: <http://sigsif.agricultura.gov.br/sigsif cons/!sigsif.ap_condenacao_especie_rep_cons>. Accessed on: Aug. 10, 2017.

Bucklin, R. A.; Jacob, J. P.; Mather, F. B.; Leary, J. D. and Nääs, I. A. 2009. Tunnel ventilation of broiler houses. Florida Cooperative Extension Service, Institute of Food and Agricultural Sciences, University of Florida, Gainesville. PS-46.

Calefi, A. S.; Quinteiro-Filho, W. M.; Ferreira, A. J. P. and Palermo-Neto, J. 2017. Neuroimmunomodulation and heat stress in poultry. World's Poultry Science Journal 73:493-504. https://doi.org/10.1017/S0043933917000472

Cechin, A.; Bijman, J.; Pascucci, S.; Zylbersztajn, D. and Omta, O. 2013. Quality in Cooperatives versus Investor-owned Firms: Evidence from broiler production in Paraná, Brazil. Managerial and Decision Economics 34:230-243. https://doi. org/10.1002/mde.2586

Cordeiro, M. B.; Tinôco, I. F. F.; Mesquita Filho, R. M. and Sousa, F. C. 2011. Análise de imagens digitais para a avaliação do comportamento de pintainhos de corte. Engenharia Agrícola 31:418-426. https://doi.org/10.1590/S010069162011000300002

R. Bras. Zootec., 48:e20180046, 2019 
Corrêa, F. A. F. 2013. Pesquisa de bactérias com determinação do perfil de sensibilidade em vísceras comestíveis de frango de corte, penas e camas de aviários. Dissertação (M.Sc.). Universidade Federal de Goiás, Goiânia.

Deaton, J. W.; Reece, F. N. and McNaughton, J. L. 1997. The effect of temperature during the growing period on broiler performance. Poultry Science 57:1070-1074. https://doi.org/10.3382/ps.0571070

Dozier, W. A.; Thaxton, J. P.; Branton, S. L.; Morgan, G. W.; Miles, D. M.; Roush, W. B.; Lott, B. D. and Vizzier-Thaxton, Y. 2005. Stocking density effects on growth performance and processing yields of heavy broilers. Poultry Science 84:1332-1338. https://doi.org/10.1093/ps/84.8.1332

Ebling, P. D. and Basurco, V. 2016. Análise das perdas econômicas oriundas da condenação de carcaças nos principais estados brasileiros produtores de frangos de corte. Ciências Agroveterinárias e Alimentos. Available at: <http://revista. faifaculdades.edu.br/index.php/cava/article/view/193/88>. Accessed on: Sept. 8, 2017.

Embrapa - Empresa Brasileira de Pesquisa Agropecuária. 2015. Banco de dados do guia clima mobile. Embrapa Agropecuária Oeste, Dourados. Available at: <http://mob.cpao.embrapa.br/?lc=site/banco-dados/base_dados $>$. Accessed on: Sept. 8, 2017.

Fiorentin, L. 2015. Aspectos bacteriológicos da reutilização da cama de aviários de frangos de corte. Available at: <http://www.nordesterural.com.br/nordesterural/matler.asp?newsId=2833>. Accessed on: Oct. 20, 2017.

Garcia, R. G.; Mendes, A. A.; Garcia, E. A.; Nääs, I. A.; Moreira, J.; Almeida, I. C. L. and Takita, T. S. 2002. Efeito da densidade de criação e do sexo sobre o empenamento, incidência de lesões na carcaça e qualidade da carne de peito de frangos de corte. Revista Brasileira de Ciência Avícola 4:1-9.

Gates, R. S.; Ursy, J. L.; Nienaber, J. A.; Turner, L. W. and Bridges, T. C. 1991. Optimal misting method for cooling livestock housing. Transactions of the ASABE 35:2199-2206.

IBGE - Instituto Brasileiro de Geografia e Estatística. 1990. Divisão geográfica do Brasil em mesorregiões e microrregiões geográficas. IBGE, Rio de Janeiro. Available at: <https://biblioteca.ibge.gov.br/visualizacao/livros/liv2269_1.pdf>. Accessed on: Sept. 8, 2017.

Knowles, T. G.; Kestin, S. C.; Haslam, S. M.; Brown, S. N.; Green, L. E.; Butterworth, A.; Pope, S. J.; Pfeiffer, D. and Nicol, C. J. 2008. Leg disorders in broiler chickens: prevalence, risk factors and prevention. PLoS One 3:e1545. https://doi.org/10.1371/journal.pone.0001545

Lara, L. J. and Rostagno, M. H. 2013. Impact of heat stress on poultry production. Animals 3:356-369.

Lin, H.; Decuypere, E. and Buyse, J. 2006. Acute heat stress induces oxidative stress in broiler chickens. Comparative Biochemistry and Physiology Part A: Molecular and Integrative Physiology 144:11-17. https://doi. org/10.1016/j.cbpa.2006.01.032

Macahyba, R. B.; Mano, S. B.; Freitas, M. Q. and Baptista, R. F. 2005. Condenações post-mortem em perus (Meleagris gallopavo) criados na Região Oeste Catarinense e abatidos sob Inspeção Federal. Revista Brasileira de Ciência Veterinária 12:53-57.

Macari, M. and Givisiez, P. E. N. 2002. Fisiologia respiratória. In: Fisiologia aviária aplicada a frangos de corte. Macari, M.; Furlan, R. L. and Gonzales, E., eds. FACTA, São Paulo.

Miragliotta, M. Y.; Nääs, I. A.; Manzione, R. L. and Nascimento, F. F. 2006. Spatial analysis of stress conditions inside broiler house under tunnel ventilation. Scientia Agricola 63:426-432. https://doi.org/10.1590/S0103-90162006000500002

Mortari, A. C.; Rosa, A. P.; Zanella, I.; Beretta Neto, C.; Viscentini, P. B. and Brites, L. B. P. 2002. Desempenho de frangos de corte criados em diferentes densidades populacionais, no inverno, no sul do Brasil. Ciência Rural 32:493-497. https://doi.org/10.1590/S0103-84782002000300020

Moura, M. S.; Reis, D. O.; Carreon, R. S.; Araújo, L. B.; Araújo, M. F. C.; Carrijo, K. F. and Cardoso, R. 2012. Causas de condenações post-mortem de perus abatidos em estabelecimento com Serviço de Inspeção Federal (SIF) no estado de Minas Gerais, Brasil. Revista Brasileira de Ciências Veterinárias 19:7-12. https://doi.org/10.4322/rbcv.2014.075

Nascimento, S. T.; Silva, I. J. O.; Rodrigues, V. C. and Nunes, M. L. A. 2009. Estudos preliminares de tolerância ao estresse térmico de duas linhagens comerciais de frangos de corte na sexta semana de produção. In: XVIII Congresso de Zootecnia; II Congresso Ibero-Americano de Zootecnia, Vila Real, Portugal. Livro de Comunicações, p.474-477.

Olivo, R. 2006. 0 mundo do frango: cadeia produtiva da carne de frango. Varela Press, Criciúma.

Paschoal, E. C.; Otutumi, L. K. and Silveira, A. P. 2012. Principais causas de condenações no abate de frangos de corte de um abatedouro localizado na região noroeste do Paraná, Brasil. Arquivos de Ciências Veterinárias e Zoologia da UNIPAR 15:93-97.

Salines, M.; Allain, V.; Roul, H.; Magras, C. and Le Bouquin, S. 2017. Rates of and reasons for condemnation of poultry carcasses: harmonised methodology at the slaughterhouse. The Veterinary Record 180:516. https://doi org/10.1136/vr.104000

Santana, A. P.; Murata, L. S.; Freitas, C. G.; Delphino, M. K. and Pimentel, C. M. 2008. Causes of condemnation of carcasses from poultry in slaughterhouses located in State of Goiás, Brazil. Ciência Rural 38:2587-2592. https://doi.org/10.1590/ S0103-84782008005000002

R. Bras. Zootec., 48:e20180046, 2019 
Santos, C. C. 2007. Mecanismos adaptativos em frangos submetidos a estresse térmico agudo pré abate e suas implicações na funcionalidade proteica muscular. Dissertação (M.Sc.). Universidade de São Paulo, Escola Superior de Agricultura "Luiz de Queiroz", Piracicaba.

Schlestein, A. 2007. Avaliação das causas de condenações de perus (Meleagris gallopavo) em 2005 e 2006 no estado do Rio Grande do Sul. Dissertação (M.Sc.). Universidade Federal de Santa Maria, Santa Maria.

Sesterhenn, R.; Ferreira, T. Z.; Kindlein, L. and Moraes, H. L. S. 2011. Impacto econômico de condenações post mortem de aves sob inspeção estadual no estado do Rio Grande do Sul. In: Anais do 38ㅜㅡ Congresso Brasileiro de Medicina Veterinária, Florianópolis. CONBRAVET, Florianópolis.

Sorensen, P.; Su, G. and Kestin, S. C. 2000. Effects of age and stocking density on leg weakness in broiler chickens. Poultry Science 79:864-870. https://doi.org/10.1093/ps/79.6.864

Souza, V. L. F.; Buranelo, G. S.; Gaspariano, E.; Cardoso, R. M. and Barbosa, M. J. B. 2010. Efeito da automatização nas diferentes estações do ano sobre os parâmetros de desempenho, rendimento e qualidade da carne de frango de corte. Acta Scientiarum. Animal Sciences 32:175-181. 